\title{
Down on the farm and barefoot in the kitchen: farm labour and domestic labour as forms of servitude
}

\author{
Stu Woolman \& Michael Bishop ${ }^{1}$
}

This article evaluates the claim that working conditions for farm workers and domestic workers in South Africa can be analysed in terms of the constitutional prohibition against servitude. Recent research and statistics suggest that for most of these workers the conditions fit the accepted definition of servitude. Although a finding that the constitutional right to be free from servitude has been violated is not a straightforward matter, the existing research provides the empirical and legal predicates for such a finding. The appropriate remedy for violations of the 1996 Constitution's prohibition against servitude is the creation, by the state, of a comprehensive and coordinated programme designed to realise the manumission of these workers. The use of law as a tool for social transformation has inherent limits. At a minimum, however, a legal finding of such a constitutional infraction obliges the state to employ all available means at its disposal to restore the dignity of these workers.

No one may be subjected to slavery, servitude or forced labour. (Constitution of the Republic of South Africa, Section 13)

\section{INTRODUCTION}

Terms such as slavery and servitude can seem quaint, depicting conditions of existence in an age that falls closer to the Palaeolithic than the present. For the upwards of 200 million persons held in some coeval form of bondage, however, the terms describe something all too human and all too real.

Slavery and servitude are also not things that happen elsewhere - like the thunder of a distant war. They are deeply entrenched, if not ineradicable, features of the South African landscape. In this paper, we describe two sets of circumstances that are best characterised as conditions of servitude: farm labour and domestic labour. Our claim is not that all farm labour and all domestic labour occur under conditions of servitude. It is, rather, that since quite a significant amount of farm labour and domestic labour can be characterised as such, we should be using all the tools at our disposal to eradicate this particular mischief. One of these tools is the Final Constitution. ${ }^{1}$

However, to say that the Final Constitution, and in particular FC s 13, sets its face against these pernicious practices does not tell us what our basic law can do about them. The purpose of this paper is to demonstrate that the broadly worded norms in our basic law, and the specific kinds of remedies it affords, do speak to the conditions of servitude

'Respectively, Senior Lecturer, School of Law, University of Pretoria, Research Associate, Centre for Human Rights, University of Pretoria, Research Associate, SAIFAC (South African Institute For Advanced Constitutional, Human Rights, Public and International Law), and Editor-in-Chief, Constitutional Law of South Africa; and Research Associate, Centre for Human Rights, University of Pretoria, and Clerk, Chief Justice Pius Langa, Constitutional Court of South Africa, 'in this paper we refer to both the Final Constitution of the Republic of South Africa Act 108 of 1996 (FC) and the Interim Constitution of the Republic of South Africa Act 200 of 1993 (IC). 
in which millions of South Africans find themselves. In Section 2 we sketch a working definition of servitude; in Sections 3 and 4 we apply that definition to farm labour and domestic labour, respectively; and in Section 5 we draw some provisional conclusions about the limits of constitutional law with respect to the eradication of such evils.

\section{WORKING DEFINITION OF SERVITUDE}

The Supplementary Convention on the Abolition of Slavery (OHCHR, 1956) provides a useful departure point for defining servitude. (Although South Africa has not ratified this convention, it nevertheless reflects the international community's understanding of the concept of servitude and, in terms of FC s 232 and 233, must inform our process of constitutional interpretation; see De Waal et al., 2001; Strydom \& Hopkins, 2005.) Article 1 of this Convention identifies the following prohibited practices as servitude:

(a) Debt bondage, that is to say, the status or condition arising from a pledge by a debtor of his personal services or of those of a person under his control as security for a debt, if the value of those services reasonably assessed is not applied towards the liquidation of the debt or the length and nature of those services are not respectively limited and defined;

(b) Serfdom, that is to say, the condition or status of a tenant who is by law, custom or agreement bound to live and labour on land belonging to another person and to render some determinate service to such other person, whether for reward or not, and is not free to change his status;

(c) Any institution or practice whereby:

(i) A woman, without the right to refuse, is promised or given in marriage on payment of a consideration in money or in kind to her parents, guardian, family or any other person or group; or

(ii) The husband of a woman, his family, or his clan, has the right to transfer her to another person for value received or otherwise; or

(iii) A woman on the death of her husband is liable to be inherited by another person;

(d) Any institution or practice whereby a child or young person under the age of 18 years is delivered by either or both of his natural parents or by his guardian to another person, whether for reward or not, with a view to the exploitation of the child or young person or of his labour.

How does servitude differ from slavery? Most international human rights instruments prohibit both, but remain silent about the normative grounds for a distinction between the two conditions (for example, the International Covenant on Civil and Political Rights, the European Convention for the Protection of Human Rights and Fundamental Freedoms and the Inter-American Convention on Human Rights; and see Davidson, 1998: 231-2). On our account, slavery is the exercise of the entitlements of ownership of a person by the slave-master and operates through the overt application of force or coercion (for a more detailed account, see Woolman \& Bishop, 2006). Servitude, on the other hand, is dominion underwritten by 'law, custom or agreement' ( $W, X, Y \& Z v$ The United Kingdom, 1968). But neither law, nor custom nor agreement ought to be construed to mean consent by the bondsman to his abject conditions. Consider the

Debt bondage or bonded labour occurs when a person works for a 'lender/owner' in conditions of servitude to pay off a debt, which may often have been incurred by another. The debt is rarely paid off because of the high interest rates charged. Debt bondage often looks like slavery because the debt becomes permanent and is often passed down to the next generation. 
caste conditions of an 'untouchable' in India. Members of higher castes do not exercise rights of ownership. The untouchables appear to work 'voluntarily' for all those above them. However, they are not free to change their status as untouchables because of the nature of the caste system. In sum, servitude is about status ( $W, X, Y \& Z v$ The United Kingdom, 1968).

In Coetzee v Government of the Republic of South Africa (1995) the Constitutional Court held that a provision of the Magistrates Court Act 32 of 1944 that permitted incarceration without trial of a civil debtor constituted an unjustifiable infringement of the right to freedom and security of the person. Had the Coetzee Court not had IC s 11(1) (Interim Constitution) to rely on it could have characterised civil imprisonment provisions as a species of servitude. The debtor was obliged to stay in prison because of his status - his inability to pay off a debt. The debtor's condition was not one in which the incidents of ownership were exercised by another. Moreover, his failure to remain solvent led to a further reduction in status - imprisonment. The Coetzee Court did away with these civil imprisonment provisions largely because incarceration for 'status' - and not crime - is out of step with contemporary mores \{Coetzee $v$ Government of the Republic of South Africa, 1995: paras 66-7).

Not all courts construe 'servitude' in a manner that embraces a person's social status (see tenBroek, 1951: 179-80; Colbert, 1990: 33-4). In United States v Kozminski (1988), the US Supreme Court held that the Thirteenth Amendment prohibited only 'involuntary servitude enforced by the use or threatened use of physical or legal coercion'. ${ }^{3}$ Kozminski"s cramped definition fails to engage the myriad ways in which social conventions radically constrain the conditions of lived experience (cf. Clyatt v United States, 1905: 215; United States v Reynolds, 1914). Prohibitions against servitude exist in order to disrupt social arrangements that perpetuate domination without overt resort to legal sanction or physical punishment. Contrary to the holding in Kozminski, the Final Constitution's prohibition against servitude is meant to roll back the quiet occupation of the body.

These observations generate two working definitions of servitude. Our broad definition runs as follows:

Servitude is about caste or status. Persons in conditions of servitude occupy a social station that does not allow them to alter the conditions of their existence: their station makes it appear that they work 'voluntarily' for those above them. Servitude appears voluntary because this form of dominion of man over man is underwritten by 'law, custom or agreement' and not by a particular legal relationship of control of one person over another. Such 'law, custom or agreement' refers to social understandings and not to any consent by the bondsman to abject conditions.

Our narrow definition takes this form:

${ }^{3}$ But see Asher, 1994: 252. Asher criticises the Kozminski definition for falling short of international definitions of servitude and argues for a more expansive one. See also Bailey $v$ Alabama, 1911: 243 (the Thirteenth Amendment protects the inalienability of an individual's right to his or her labour and forbids the state to enforce laws that directly or indirectly result in compulsory service); United States $v$ Reynolds, 1914 (the US Supreme Court found that a statute's constant threat of arrest and imprisonment for failure to pay a third party debt timeously turned the obligation to work into compulsory or forced labour designed to satisfy a debt and thus was a violation of the prohibition against servitude); Page, 1989; and Goluboff, 2001. 
Debt bondage occurs whenever a person is compelled to work in order to pay off a debt. However, the concept of involuntary servitude - originally grounded in indebtedness - may embrace services rendered for reasons other than indebtedness.

\section{FARM LABOUR AS SERVITUDE}

According to s 1 of the Basic Conditions of Employment Act 75 of 1997 (BCEA), a farm worker is 'an employee who is employed mainly or in connection with farming activities, and includes an employee who wholly or mainly performs domestic work in a home on a farm'.

BCEA Sectoral Determination 8 (2002) deals comprehensively with the specific working conditions of farm labourers. It defines 'farming activities' as including 'primary and secondary agriculture, mixed farming, horticulture, aqua farming and the farming of animal products or field crops excluding the Forestry Sector' and contains detailed provisions for minimum wages, manner of payment, leave and overtime work. It refers to the constitutional prohibition against forced labour (2002: s 25(4)) and adds: 'No person may for their own benefit or for the benefit of someone else cause, demand or impose forced labour' (2002: s 25(5)). Read together, the BCEA and Sectoral Determination 8 provide a comprehensive scheme for farm worker protection. Any farm labour where the labourer is forced to work in conditions significantly below the standards laid down by the sectoral determination will constitute forced labour. Despite this legal revolution, widespread non-compliance with the BCEA remains a common problem.

\footnotetext{
The most common forms of non-compliance with BCEA Sectoral Determination 8 are nonadherence to working hours; unpaid overtime (54 per cent of labourers continue work after the day officially ends without compensation); work on Sundays and public holidays; no annual leave (92 per cent of male farm workers do not receive any paid annual leave); and no maternity benefits (SAHRC, 2003: 25-6). The SAHRC (South African Human Rights Commission) identifies both the threat and the prevalence of evictions of farm workers as one of the primary problems in the sector. As a result, farm workers worry far less than they should about changing their status, and far more than they should about maintaining what little security they enjoy on the farms (SAHRC, 2003: 9).
}

Forced labour may be the most obvious problem in farm labour. However the history of farm work in South Africa is a history of servitude. Farm labourers still often live their entire lives on a farm. The de jure feudal order of farm work under apartheid has given way to de facto serfdom. Even without pass laws, today's farm workers have few options to go elsewhere and do other work:

Farm workers usually live in houses that do not belong to them. A central component of the arrangements on farms is that many workers not only work on the farms but also live there, with housing being either a form of payment in kind, or part of the terms of their contract. Thus, for many farm workers, the loss of their job means the loss of their house. The farmer is able to exercise control over the farm workers' daily bread, as well as over the roof over their heads. This increases farm workers' dependence on the farmer, and contributes significantly to the imbalance of power. (Isaacs, 2003: 36) 
The vast majority of farm workers in South Africa are unable to change their status and thus rather easily satisfy the Supplementary Convention's definition of a serf:

A tenant who is by law, custom or agreement bound to live and labour on land belonging to another person and to render some determinate service to such other person, whether for reward or not, and is not free to change his status. (OHCHR, 1956: Article 1)

In March 2004, Statistics South Africa estimated that there were 930000 people employed in commercial agriculture. (StatsSA, 2004). Approximately 914473 farm workers live with their families on farms (Wegerif, 2001: 3). Given that each worker has five to six dependants, researchers have concluded that approximately six million people live on farms. McKay (2003) states that

Farm workers earn the equivalent of \$100 Canadian per month and support an average of five dependants on that amount... Statistics South Africa predicts that the number of dependants will rise due to ... HIV/AIDS. ... $[$ F]arm ... employees are the most destitute and least educated group in South Africa. ... According to Statistics South Africa, people employed in agriculture are worse off than those in every other major sector of the economy. For black and coloured workers on farms, wages are low, housing is poor, access to education difficult or non-existent, and health indicators are bad.

Although figures vary widely, the SAHRC (2003: 13) has estimated that there are around 250000 labour tenants in South Africa. A labour tenant is defined in s 1 of the Land Reform (Labour Tenants) Act 3 of 1996 as a person who lives on a farm with a right to sharecropping and provides labour in return and whose parents lived on the farm under a similar agreement. This definition fits precisely that of a serf. The SAHRC (2003: 170) asserts that '[f]arming communities are characterised by ... skewed power dynamics between farm dwellers and farm owners' and concludes that:

The power of farm owners extends to ownership of land, employment and access to economic and social needs. Farm dwellers are dependent on employers for employment and tenure security, and in some cases, their basic economic and social rights. This pervades all aspects of life, resulting in gross power imbalances between parties. (SAHRC, 2003: 172)

Isaacs (2003: 51) argues that while government has made an effort to deal with '[t]rapped farm labour ... legislative changes ... have not substantially altered conditions on the ground'.

A prohibition on servitude makes complete sense only against a background in which people are assumed to be free to move and to alienate their labour. But what might it mean under conditions where alternative employment and housing are scarce, education and skill levels are low, and farms fail to meet statutory standards? Who would bear the burden of vindicating the rights of those millions living in servitude? Everyone. The servitude of most farm workers can no longer be viewed solely through the prism of employer-employee relations. Take the synoptic view and it becomes clear that the polycentric problem of farm workers in South Africa is a crisis of caste.

Recasting the problem of farm workers in terms of caste makes it somewhat less amenable to resolution in the adversarial setting of a court. Any remedy for this problem of 
caste must be one that engages all of the social conditions that reinforce such entrenched systemic inequality. Many farmers do not compensate their employees at the rates required nor do they create the work environment contemplated by the BCEA, Sectoral Determination 8 or other applicable legislation. The SAHRC (2003: iv-vi) states that 'despite constitutional provisions and the promulgation of legislation such as ESTA and $\mathrm{LTA}^{4}$ to protect those whose tenure on land is legally insecure, there is a clear lack of support for the legislation ... and widespread lack of compliance'. What is required is a concerted effort not only to enforce basic employment conditions but also to invest in education, redistribute land and create jobs. Described thus, such a violation of FC s 13's prohibition of servitude looks much like a failure by the state to provide access to adequate housing, health care, food, education, legal representation and social security (SAHRC, 2003: 7-56). For it is the state - and no one private party - that must be able to develop a comprehensive programme designed to progressively realise the manumission of South Africa's farm workers (cf. Scott, 1999: 6).

This constitutional burden is not, theoretically, insuperable. In Government of the Republic of South Africa v Grootboom, the Constitutional Court set out the criteria by which it would assess whether the state had discharged its duty to construct a comprehensive programme designed to progressively realise a right; in that case, the right to housing. In sum, the Court held that a state programme to eliminate servitude: (1) must ensure that 'the appropriate financial and human resources are available'; (2) 'must be capable of facilitating the realisation of the right'; (3) must be reasonable 'both in their conception and their implementation'; (4) must attend to 'crises'; (5) must not exclude 'a significant segment' of the affected population; and (6) must 'respond to the urgent needs of those in desperate situations' \{Government of the Republic of South Africa $v$ Grootboom, 2001: paras 39-46, 52, 53, 63-69, 74, 83; Brand, 2005). A state programme that meets these criteria would constitute the remedy appropriate for a violation - by the state - of FC s 13's prohibition against servitude.

The Grootboom criteria provide a useful rubric for appraising the reasonableness of the government's actions with regard to the alleviation of the more pernicious symptoms of servitude. However, the deployment of these socio-economic rights criteria is not meant to suggest that only the state can violate FC s 13: they simply draw our attention to the multi-dimensional nature of the problem of farm worker servitude. Where individual instances of servitude are a consequence of the relationship between private parties, the party responsible for creating the conditions of servitude must bear the burden of setting things right.

\section{DOMESTIC LABOUR AS SERVITUDE}

The condition of the roughly one million domestic workers in South Africa bears more than a passing resemblance to that of farm workers. According to s 1 of the BCEA, a domestic worker is 'an employee who performs domestic work in the home of his or her employer and includes - (a) a gardener; (b) a person employed by a household as driver of a motor vehicle; and (c) a person who takes care of children, the aged, the sick, the frail or the disabled'. Although the state has made significant efforts to turn this historically inhospitable informal sector of the economy into a substantially more formal and equitable sector, most domestic workers are often only notionally free to alter their conditions of employment.

The Extension of Security of Tenure Act 62 of 1997 and the Land Tenure Rights Act 112 of 1991. 
Some 1013000 women work as housekeepers, cooks and nannies, and some 218000 men as gardeners and security guards. Most of these workers are of African and coloured descent (StatsSA, 2004: v, 31, vi). Domestic workers represent roughly 9 per cent of all formal and informal employment in South Africa. However, they reflect 18.6 per cent of female employment and only 0.6 per cent of male employment (StatsSA, 2004: v). Over the past decade real wages for female domestic workers have fallen, even as real wages for skilled female workers have risen dramatically. Burger and Yu (2006: 8) observe that:

Women experienced a sharper fall in their earnings between 1995 and 1998, so that by 2005 average female earnings were still slightly below the 1995 level, whereas average male earnings were about 5 per cent higher. ... [T] earnings of unskilled and semi-skilled workers were slightly lower in 2005 than they were in 1995, whereas skilled earnings increased substantially over the same period. This is consistent with what one would expect to see in an economy with a shortage of skilled labour and an abundance of low-skilled unemployed. After a large decrease in their earnings between 1995 and 2002, the wages of unskilled workers increased by 27 per cent between 2002 and 2005, whereas the earnings growth of the highly skilled appear to have slowed down.

Other jurisdictions have analysed the hostile working environment of domestic servants in terms of slavery and servitude. In United States $v$ Ingalls, a US federal district court extended the accepted definitions of slavery and servitude beyond the specific form of ante-bellum chattel slavery towards which the Thirteenth Amendment had been directed \{United States $v$ Ingalls, 1947: 77-9). The Ingalls court wrote:

There is an abundance of evidence which establishes that the defendant Elizabeth Cocker kept one Dora L Jones, a Negro woman, in her household as a servant during a period in excess of twenty-five years ... that... said servant was required to ... perform practically all of the household labour ... was forbidden to leave the household except for the commission of errands and performed drudgery of the most menial ... type without compensation. There is evidence that the food furnished to her by the defendant was of a substantially lower quality than that common to servants generally ... [that] she was denied the right to have friends and was required to send away relative[s] who called upon her. \{United States v Ingalls, 1947: 78)

Combined with threats of imprisonment and institutionalisation, this hostile work environment created conditions of forced immobility that led Ms Jones to believe that she was not free to leave. The Ingalls court likewise concluded that Ms Jones was wholly subject to the will of the defendant, had no freedom of action and lived in a state of enforced compulsory service. As Goluboff (2001) notes, the case signals a shift in the doctrine of servitude from one anchored in clear manifestations of physical constraint and indebtedness to one focused on the actual lived experience of workers. It also signals a shift in the role of government - from that 'of policing contracts to one of ensuring labourers their freedom' (Goluboff, 2001: 1667-8).

What then should we make of recent econometric research that suggests that the situation of domestic workers may not be as dire as that of farm workers? The government has attempted to improve the labour conditions for domestic workers through BCEA 
Sectoral Determination 7 (2002), which contains detailed provisions on minimum wages (part B), working hours (part D), leave (part E) and termination of employment (part G). In November of 2002 a schedule of minimum wages, including time-and-a-half provisions for overtime work, went into effect. As Hertz (2004: 2) observes, 'The minima were set above the median hourly wages that prevailed at the time, making this a significant intervention in the domestic worker labour market'. The determination also includes a prohibition on child labour and forced labour (s 23). Hertz (2004: 1-2) contends that these regulations benefit many domestic workers and, thankfully, do them very little harm. Wages for domestic work have gone up faster than the CPI (Consumer Price Index) and faster than wages in demographic ally comparable occupational sectors:

The regulations do appear to have raised wages: average nominal hourly wages for domestic workers in September of 2003 were 23 per cent higher than they had been in September 2002, while for demographically similar workers in other occupations the nominal wage increase was less than 5 per cent. Econometric evidence supports the conclusion that the wage increases were caused by the regulations, since the largest increases are seen in places where the greatest number of workers were initially below the minimum wage. (Hertz, 2004: 1)

The regulations, Hertz (2004: 2) suggests, have had a palpable effect on non-wage labour conditions as well: 'The proportion of domestics who report having a written contract with their employer rose from 7 per cent in February of 2002 to 25 per cent in September of 2003; and the number who report Unemployment Insurance Fund (UIF) deductions rose from 3 per cent to 25 per cent.'

Even proponents of these minimum standards feared that these laws might have the unintended consequence of driving down both employment figures and real wages for domestic workers. Two years of statistics allay these concerns. While hours of work among domestic workers 'fell by about 4 per cent', this change was largely consistent with hours worked in other occupations. Moreover, while domestic worker employment levels also fell by 3 per cent, Hertz (2004: 6-9) concluded that that the decrease was not 'causally connected to the wage changes', and that the decrease was in line with 'the rate of decline of the employment-to-population ratio for demographically similar workers in other occupations'.

But, as Hertz concedes, such news is not really 'all that cheery'. Only 25 per cent of workers have a written contract and have UIF deducted. Only 22 per cent receive paid leave. Just over 10 per cent have a pension. Less than 2 per cent have any health insurance. In the light of such substantial non-compliance with the statutory and the regulatory frameworks governing domestic employees, Hertz tells us that we ought to be pleased that conditions for domestic workers are not worse and that the law has not made them so (see also Grossman, 2000).

Given Hertz's analysis, the crisp question is whether the presence of this regulatory framework is sufficient to discharge the state's obligations under FC s 13. As Brand (2005: para. 56.3) notes in his analysis of the government's efforts to fulfil its duties under FC s 27 (the right to food), the government must do more than simply craft a reasonable response to a constitutionally suspect set of practices. It must effectively execute its policies. FC s 13 and BCEA Sectoral Determination 7 offer some consolation to those individual workers who have access to legal representation and the promise of alternative employment: but neither protects the vast majority of domestic workers who 
lack either adequate counsel or new work. To discharge its duty to promote and to fulfil the rights of domestic workers, the state must develop a more comprehensive and coordinated programme to progressively realise their manumission.

\section{CONCLUSIONS}

\subsection{A provisional assessment}

The economic exigencies of South African life place limits on constitutional construction. All South African lawyers know - though not all South Africans know - that the language of the Final Constitution only requires that the state undertake reasonable steps to progressively realise various socio-economic rights (Liebenberg, 2003). The real problem is this: structural unemployment is so high and so resistant to neo-liberal, macro-economic policy interventions that only the most extravagant government programme may be able to manumit farm workers and domestic labourers (see Legum, 2003, who says: 'With few exceptions, skills are not the problem. More education and more skills means more skilled and educated unemployed people')- If this is so - and we do not wish to be misunderstood as maintaining such at this juncture - then it might well constrain our assessment as to whether or not the state has discharged its duty to eliminate all constitutionally suspect forms of servitude. In other words, the kinds of social conditions in an advanced western democracy that might lead us to declare unequivocally that a violation of FC s 13 has occurred might not warrant a similar assessment here: not because we are disinclined to view the conditions as constitutionally suspect, but because we currently lack the capacity to fundamentally alter them.

This last observation - with which some may well differ - is underwritten by a certain modesty that experience imposes upon constitutional lawyers. Much as we might like the courts to be engines of social change in the service of ends we believe to be noble and true, they lack the requisite authority to bring about - on their own - radical transformation. Courts are good at resolving discrete disputes and putting parties on notice that they have not discharged their duties; they are less well designed to institute and manage complicated and wide-ranging social change. What we have tried to suggest in the foregoing account is that many domestic workers and farm labourers toil in conditions of servitude in South Africa and that a FC s 13 challenge might just put the government on notice that it needs to create a comprehensive and coordinated programme to restore the dignity of these individuals.

\subsection{A cautionary note}

Some commentators worry that the kinds of legal reforms contemplated in this paper could do significant harm to the security of both farm workers' and domestic workers' livelihoods. For example, the literature on farm workers suggests a growing consensus among sociologists and agricultural economists that ESTA may have caused more harm than good. Lahiff (2001: 2-3) writes:

On the farms,... ESTA has had little success in preventing illegal evictions. This can be largely attributed to complicity of magistrates, and police in farming districts, the collapse of the legal aid system, the lack of capacity for implementation by the Department of Land Affairs, and above all, widespread disregard for the law by landowners. In theory, ESTA provides protection for people who live on land in rural or peri-urban areas with the permission of the owner of that land, regardless of whether or not they are 
employed by the landowner or not. While the Act makes it more difficult to evict occupiers of farm housing, evictions are still possible in many cases. Evicted people who are unable to find alternative accommodation on farms are generally given low priority on municipal housing lists, and often end up squatting in informal settlements or in nearby communities.

Ruth Hall (2003) has recently offered an even more scathing indictment of ESTA-based land reforms. After running through the standard litany of illegal evictions, legal underenforcement, lack of institutional capacity, the absence of legal awareness of rights and the concomitant paucity of adequate representation, Hall (2003: 22) sums up ESTA's failings as follows:

ESTA is, nominally, a 'balanced' piece of legislation in that it imposes obligations on both farm dwellers and owners, as well as creating rights. What is surprising is that such an apparently even-handed law is to be applied to such a strikingly unequal set of social and economic relations - without the power to transform them. It also combines weak substantive rights with strong procedural requirements and relies on institutions that are at worst hostile to ESTA and at best inadequately resourced and coordinated to enforce these procedural rights.

Implicit in critiques of both ESTA and other notionally pro-farm worker legislation is the view that even a properly conceived and fully executed state programme may fail to enable farm labourers to move off the land into other forms of gainful employment. Again, what such critics imply is that our suggested reforms may make the labour conditions of farm workers and domestic workers less secure. This implication has more than rhetorical force. Given the high levels of structural unemployment in our economy, it is certainly plausible that well-serviced farm workers and their families might still lack new and meaningful work opportunities.

We would argue, nevertheless, that even under such conditions an appropriate state response to a FC s 13 or a FC s 10 (the right to dignity) challenge could result in the discharge of the government's constitutional duties. For although the farm workers and their families would still 'belong' to the land, the actual improvement in their quality of life would elevate their status well above that of serfs. The state's first obligation is the dignity of its citizens. A comprehensive programme that addresses the education, health care, and physical security of farm workers would afford them that dignity (Woolman, 2005).

\section{REFERENCES}

ASHER, J, 1994. How the United States is violating international agreements to combat slavery. Emory International Law Review, 4: 215.

Bailey v Alabama (1911) 219 US 219.

BRAND, D, 2005. Food. In Woolman, S, Roux, T, Klaaren, J, Stein, A, Chaskalson, M \& Bishop, M (Eds), Constitutional law of South Africa (2nd edition, OS), chapter 56C. Cape Town: Juta Law.

BURGER, R \& YU, D, 2006. Wage trends in post-Apartheid South Africa: constructing an earnings series from household survey data. Reserve Bank of South Africa.

Clyatt v United States (1905) 197 US 207.

Coetzee v Government of the Republic of South Africa (1995) (4) SA 631 (CC), 1995 (10)

BCLR 1382 (CC). 
COLBERT, D, 1990. Challenging the challenge: Thirteenth Amendment as a prohibition against the racial use of peremptory challenges. Cornell Law Review, 76: 1.

DAVIDSON, S, 1998. The civil and political rights protected in the inter-American human rights system. In Harris, DJ \& Livingstone, S (Eds), The inter-American system of human rights. Oxford: Clarendon.

DE WAAL, J, CURRIE, I \& ERASMUS, G, 2001. The Bill of Rights handbook (4th edition). Cape Town: Juta Law.

GOLUBOFF, R, 2001. The 13th Amendment and the lost origins of civil rights. Duke Law Journal, 50: 1609.

Government of the Republic of South Africa v Grootboom (2001) (1) SA 46 (CC), 2000 (11)BCLR 1169 (CC).

GROSSMAN, J, 2000. Workers and transition: an investigation of domestic workers' experience of change and continuity. Report to the National Research Foundation. HALL, R, 2003. Evaluating land and agrarian reform in South Africa: farm tenure. Programme for Land and Agrarian Studies, University of the Western Cape, Cape Town.

HERTZ, T, 2004. Have minimum wages benefited South Africa's domestic service workers? African development and poverty reduction forum, Paper 4 (13 October). ISAACS, A, 2003. Trapped farm labour: obstacles to rights and freedom. Development Update, 27.

LAHIFF, E, 2001. Land reform in South Africa: is it meeting the challenge? Debating land reform and rural development (September). Programme for Land and Agrarian Studies. University of the Western Cape, Cape Town.

LEGUM, M, 2003. Livelihoods, not employment. South African New Economics, 3(22): 1 .

LIEBENBERG, S, 2003. Interpretation of socio-economic rights. In Woolman, S, Roux, T, Klaaren, J, Stein, A, Chaskalson, M \& Bishop, M (Eds), Constitutional law of South Africa (2nd edition, OS), chapter 33. Cape Town: Juta Law.

MCKAY, K, 2003. Farm workers in the Karoo: isolation = exploitation. (Manuscript on file with authors.)

OHCHR (OFFICE OF THE HIGH COMMISSIONER FOR HUMAN RIGHTS), 1956. Supplementary Convention on the Abolition of Slavery, the Slave Trade and Institutions and Practices Similar to Slavery. Geneva, Switzerland, http://www.unhchr.ch/html/ menu3/b/30.htm Accessed 7 June 2007.

PAGE, CM, 1989. United States $v$ Kozminski: involuntary servitude - a standard at last. University of Toledo Law Review, 20: 1023.

SAHRC (SOUTH AFRICAN HUMAN RIGHTS COMMISSION), 2003. Inquiry into human rights in farming communities, http://www.sahrc.org.za Accessed 7 June 2007. SCOTT, C, 1999. Social rights: towards a principled pragmatic judicial role. Economic and Social Rights Review, 1(4): 4.

Sectoral Determination 7: Domestic Worker Sector, GN R1068 Government Gazette 23732 (15 August 2002).

Sectoral Determination 8: Farm Worker Sector, GN R1499, Government Gazette 24114 (2 December 2002).

STATSSA (STATISTICS SOUTH AFRICA), 2004. Labour force survey, http:// www.statssa.gov.za Accessed 25 December 2004.

STRYDOM, H \& HOPKINS, K, 2005. International law and agreements. In Woolman, S, Roux, T, Klaaren, J, Stein, A, Chaskalson, M \& Bishop, M (Eds), Constitutional law of South Africa (2nd edition, OS), chapter 36. Cape Town: Juta Law. 
TENBROEK, J, 1951. Thirteenth Amendment to the Constitution of the United States: consummation to abolition and the key to the Fourteenth Amendment. California Law Review, 39: 171.

United States v Ingalls 73 F Supp 76, 77 - 79 (SD Cal 1947).

United States $v$ Kozminski (1988) 487 US 931.

United States $v$ Reynolds (1914) 235 US 133.

WEGERIF, M, 2001. Creating long-term security of tenure for farm dwellers. Paper presented at Department of Land Affairs National Land Tenure Conference. September, Durban. (Manuscript on file with authors.)

WOOLMAN, S, 2005. Dignity. In Woolman, S, Roux, T, Klaaren, J, Stein, A, Chaskalson, M \& Bishop, M (Eds), Constitutional law of South Africa (2nd edition, OS), chapter 36. Cape Town: Juta Law.

WOOLMAN, S \& BISHOP, M, 2006. State as pimp: sexual slavery in South Africa. Development South Africa, 23(3): 385-400.

W, X, Y \& Z v The United Kingdom (1968) 11 Yearbook of the European Convention on Human Rights 562. 